\title{
Motivational-Ideational Analysis of Stalin's Foreign Policy
}

Professor Tucker's twofold task in "The Emergence of Stalin's Foreign Policy"
is both to describe Stalin's "thinking" about foreign policy and to explain Stalin's
"practice" of foreign policy, particularly toward the West. With regard to Stalin's
thinking, Tucker's approach takes place on two levels. On one hand, his investi-
gation of Stalin's attitudes, motives, and purposes leads to basically psychological
phenomena. These are largely unconscious and implicit in Stalin's writings and
speeches. Specifically, Tucker assigns importance to two identity formations : (1)

Stalin's self-identification as leader of the successor state to historic Russiacausing him to favor internal and external policies that would make Soviet Russia a world power-and (2) Stalin's self-identification with and competitiveness with Lenin-compelling him to aspire to bring about a "better Brest-Litovsk" providing Soviet Russia with additional territory and ultimate security in the form of contiguous socialist states.

On the other hand, Professor Tucker's examination of Stalin's conceptual framework for foreign policy-Russia's position in the world, goals, strategy, tactics, and so forth-deals basically in ideational and ideological constructs. These are for the most part conscious and explicit in Stalin's utterances. On this plane of analysis, Tucker concludes that Stalin believed that Soviet Russia might survive in a hostile international environment where war was inevitable and might eventually attain a commanding world position by úsing divisive diplomacy in order to: (1) avert war while building military strength, (2) precipitate war at the right moment, and (3) avoid participation during the war's early stages. Russia would enter such a war only when to do so would result in territorial aggrandizement and the expansion of socialism through "guided revolution" in adjacent countries.

Although Professor Tucker skillfully interweaves the psychological and ideological levels into a single motivational-ideational interpretation of Stalin's thinking, the two psychological identity formations serve an important function for the whole. The Lenin identification suggests why Stalin uniquely stressed war as the manner in which Russia would regain territory and spread revolution. The Great Russian national-historic identification explains why Stalin considered that the path of territorial aggrandizement and revolutionary advance would be in areas near the present Russian borders. And not least important, both identity formations lend support to the view that Stalin's commitment to the goals of territorial and revolutionary expansion was real rather than ritualistic.

Concurring with Professor Tucker's overall formulation of Stalin's thinking about foreign policy, I would make some observations concerning certain details. If, as Tucker suggests, Stalin changed his 1926 concept of "armed revolution" into one that was centered on his own Red Army, this revised notion was perhaps the more compelling because it was consistent with one of Lenin's passages that Stalin frequently cited in support of his own theory of socialism in one country. In 1915 Lenin had written: 
The victorious proletariat of that country, having expropriated the capitalists and organized its own socialist production [italics Stalin's], would rise against the rest of the capitalist world, attract to itself the oppressed classes of other countries, raise revolts among them against the capitalists, and in the event of necessity, come out even with armed force against the exploiting classes and their states [italics mine]. ${ }^{1}$

Moreover, it is worth noting that Stalin cynically assumed that capitalist powers were attempting to practice the same devious diplomacy toward Soviet Russia that he sought to use against them. I would stress the depth of Stalin's caution in diplomacy and his fear of being tricked. ${ }^{2}$ Finally, I would point out that Stalin's method of analyzing international politics involved carefully weighing the resources (a favorite term was the "reserve") of each actor. ${ }^{3}$ Such power calculations provided a basis for Stalin's actions to realize his purposes in foreign policy and for his measurement of progress or lack of progress toward achieving them.

When Professor Tucker turns to his second major task, explaining Stalin's practice of foreign policy, he stresses the dictator's thinking about foreign policy. In other words, Tucker presents a motivational-ideational (for the sake of brevity let us call it "purposive") interpretation of Stalin's practice of foreign policy. For his purposive interpretation to be persuasive, Tucker might be expected to uphold at the minimum two propositions. First, that Stalin in fact determined particular foreign policies. Because Stalin participated in ruling Politburo coalitions during the mid-1920s, it is sometimes difficult before 1928 to decide what degree of responsibility for foreign policy was Stalin's. For example, although Stalin initially opposed the idea, the Politburo in 1923 sanctioned an unsuccessful bid for power by the German Communist party. ${ }^{4}$ Stalin's final position on the revolutionary plan is simply unknown to us. Happily, Tucker excludes policies where Stalin's sponsorship is dubious and concentrates on policies where Stalin's imprint can be inferred-for example, the National Bolshevism line during 1923 in Germany.

Second, Professor Tucker's purposive thesis implies that Stalin's practice of foreign policy was basically not a response to domestic political pressure. Although this statement may be readily accepted for the 1930s, there are instances in the 1920s where Stalin's policies appeared to reflect his interest in demolishing his domestic political opponents more than his purposes in foreign policy. For example, the most persuasive explanation of the Nanchang, Autumn Crop, and Canton insurrections of late 1927 is that Stalin demanded them in order to confound his critics among the United Opposition. ${ }^{5}$ Again, the "left turn" in Comintern policy that took place between 1927 and 1929 seemed principally designed

1. Joseph V. Stalin, Problems of Leninism (New York, 1934), p. 69.

2. See Milovan Djilas, Conversations with Stalin (New York, 1962), p. 73.

3. See Stalin's memorandum to Zinoviev and Bukharin, August 1923, in Leon Trotsky, Stalin: An Appraisal of the Man and His Infuence (New York, 1941), pp. 368-69.

4. Ibid.; and Helmut Gruber, International Communism in the Era of Lenin: A Documentary History (Ithaca, N.Y., 1967), pp. 438-41.

5. Robert C. North, Moscow and Chinese Conmmunists, 2nd ed. (Stanford, Calif., 1963). 
by Stalin as a weapon against Bukharinist and other Russian opponents. ${ }^{6}$ Admittedly, we do not know Tucker's interpretation of these cases. In my view they are much less amenable to his purposive interpretation than the particular policies he does discuss.

Inevitably, Professor Tucker's purposive interpretation raises the question of whether Soviet foreign policy would have been very different under someone else like Trotsky or Bukharin. Granting a measure of shared Bolshevik (Leninist) assumptions among all three men, and assuming a similar foreign environment and comparable role expectations for any leader of the successor state to historic Russia, one is hard put to assert with confidence how Trotsky's or Bukharin's foreign policy would have differed from Stalin's. Some of Trotsky's disagreements with Stalin over foreign policy, like his advocacy of a united front in Germany against Hitler, may have resulted, not from differences of purpose, but from the fact that Trotsky was in opposition. Although Trotsky in 1927 favored greater revolutionary independence for the Chinese Communists than Stalin, Trotsky did not always take the more revolutionary stance. Thus, in 1920 when Stalin backed extension of revolutionary war into Poland, Trotsky came out against it. ${ }^{7}$ And in 1926 the two men appeared in essential agreement on policy toward the Chinese revolution. ${ }^{8}$ Although Bukharin in 1928 would probably not have imposed Stalin's military-industrial program on Russia, one cannot rule out the possibility that the subsequent darkening of the international scene (including the 1929 clashes along the Chinese Eastern Railway and the 1930 electoral success of the Nazi party in Germany) would have prompted Bukharin to adopt belated measures along Stalinist lines. The possibility that the foreign policies of the three men would have been similar suggests that there are limits to the motivational-ideational approach to Stalin's foreign policy.

Such speculation aside, the fundamental issue is Stalin's foreign policy and whether Stalin's thinking explains his practice. In my view, Professor Tucker's purposive interpretation explains a great deal about Stalin's foreign policy. Indeed, I am impressed with its usefulness in illuminating policy toward the Far East, which Tucker treats cursorily. In regard to the Far East, he chiefly observes that the China theater presents an example of the Leninist policy of allying with revolutionary nationalism (the Kuomintang) against the imperialist powers. At the same time, however, Soviet policy sought to court Chinese opponents of the Kuomintang including the warlords Wu P'ei-fu and Chang Tso-lin and the socalled Christian General Feng Yü-hsiang. Moreover, a Soviet document of March 1926 containing the decisions of a special Politburo Commission on the Far East (in which Stalin and Trotsky participated) reveals that Soviet policy was then principally concerned to prevent the formation of an Anglo-Japanese "united imperialist front." In order to further the "policy of aggravating the contra-

6. Concerning the Comintern's "New Course," Helmut Gruber asserts: "More than any previous policy of the Comintern it was the outgrowth of the continuing power struggle among Russian leaders and factions, whose final outcome established the hegemony of Stalin in Russia and in the communist movement" (Helmut Gruber, Soviet Russia Masters the Comintern: International Communism in the Era of Stalin's Ascendancy [Garden City, N.Y., 1974], p. 176).

7. Trotsky, Stalin, p. 328.

8. See below. 
dictions among the imperialist powers in the Far East," the Commission proposed to seek some agreement with Japan at the expense of Chang Tso-lin and the Kuomintang. In an amendment to the document, Stalin emphatically rejected any actions by the Chinese nationalists, including offensive military expeditions, that might "impel the imperialists onto the path of military intervention." this document it is clear that Stalin was associated with the policy of coming to terms with Japan in order to intensify interimperialist rivalries-a foreshadowing of the sale to Japan of the Chinese Eastern Railway and the conclusion of the Soviet-Japanese neutrality pact, which pointed Japan toward war with the West. Virtually the only elements of Tucker's formulation of Stalin's thinking that remain opaque or indistinct in Stalin's practice of policy toward the Far East are the specific adjacent territories where for historic or strategic reasons he might have hoped to impose from above a socialist revolution. ${ }^{10}$

More important, Professor Tucker's purposive thesis serves well in fathoming Stalin's policy toward Germany during the rise of Hitler and immediately thereafter. The main fact to be explained is that while Stalin did not actively aid Hitler's coming to power, he did nothing to prevent it. What mattered to Stalin was not the foreseeable massacre of the German Communists, but the anticipated extreme exacerbation of Franco-German relations. It is doubtful that Stalin took seriously the proposition that a democratic Weimar government might conclude an alliance with France against Russia, but he may well have decided that a democratic Germany would "never go to war against the West for German interests." To be sure, Stalin wanted no immediate war, but neither did he wish a prolonged peace.

9. "Decisions of a Special Commission of the Soviet Politburo on Far Eastern Policy" (March 25, 1926), in Gruber, International Communism in the Era of Lenin, pp. 463-67.

10. Presumably, Stalin thought primarily in terms of bases and privileges in relation to the Far East. 